\title{
Kecemasan dan Motivasi Belajar Siswa SMP Terhadap Matematika Berdasarkan Gender di Masa Pandemi COVID-19
}

\author{
Rizka Akmalia ${ }^{1}$, Syafika Ulfah ${ }^{2}$ \\ ${ }^{1,2}$ Prodi Pendidikan Matematika, Fakultas Keguruan dan Ilmu Pendidikan, Universitas Muhammadiyah Prof. Dr. HAMKA, \\ Jl. Tanah Merdeka No. 20, Jakarta Timur, Indonesia \\ Rizkaakmalia21@gmail.com
}

\begin{abstract}
During the COVID-19 pandemic, the learning system was transformed into online learning. This change in learning system can have an impact on all levels of education. The purpose of this research is to investigate the level of anxiety and student learning motivation towards mathematics by gender during the COVID-19 pandemic. This type of research is quantitative. The participants of the study were 451 students of state junior high school 8th grade in South Jakarta. The type of instrument used was a questionnaire. The instruments consisted of mathematics anxiety and learning motivation statements. The analysis used in this research is descriptive analysis. The results showed that the overall mathematics anxiety was in the moderate category. While the motivation of students' learning during the pandemic is included in the high category. Besides, female students have higher levels of anxiety $(\bar{x}=2,93$ and SS $=0,01)$ than male students $(\bar{x}=2,72$ and SS $=0,13)$. Similarly, female students have higher learning motivation $(\bar{x}$ $=3,89$ and $\mathrm{SS}=0,07)$ than male students $(\bar{x}=3,79$ and $\mathrm{SS}=0,10)$.
\end{abstract}

Keywords: Math anxiety, gender, learning motivation, COVID-19 pandemic

\begin{abstract}
Abstrak
Di masa pandemic COVID-19, system pembelajaran berubah menjadi pembelajaran daring. Adanya perubahan sistem pembelajaran ini dapat berdampak untuk seluruh lapisan pendidikan. Tujuan dari penelitian ini adalah untuk mengetahui tingkat kecemasan dan motivasi belajar siswa terhadap matematika berdasarkan gender di masa pandemic COVID-19. Jenis penelitian ini adalah kuantitatif. Responden dalam penelitian ini sebanyak 451 siswa SMP Negeri kelas 8 di Jakarta Selatan. Jenis instrumen yang digunakan adalah angket. Intrumen terdiri dari pernyataan-pernyataan kecemasan matematika dan motivasi belajar. Analisis yang digunakan dalam penelitian ini adalah analisis deskriptif. Hasil penelitian menunjukkan bahwa secara keseluruhan kecemasan matematika di masa pandemic COVID-19 termasuk ke dalam kategori sedang. Sedangkan motivasi belajar siswa pada masa pandemic ini termasuk ke dalam kategori tinggi. Selain itu siswa perempuan memiliki tingkat kecemasan matematika yang lebih tinggi $(\bar{x}=2,93$ dan SS $=0,01)$ dari pada siswa laki-laki $(\bar{x}=2,72$ dan SS $=0,13)$. Begitu juga dengan motivasi belajar, siswa perempuan memiliki motivasi yang lebih tinggi $(\bar{x}=3,89$ dan SS $=0,07)$ dibandingkan siswa laki-laki $(\bar{x}=3,79$ dan SS $=0,10)$.
\end{abstract}

Kata kunci: Kecemasan matematika, gender, motivasi belajar, pandemic COVID-19

Copyright (c) 2021 Rizka Akmalia, Syafika Ulfah

$\triangle$ Corresponding author: Rizka Akmalia

Email Address: rizkaakmalia21@ gmail.com (Jl. Tanah Merdeka No. 20, Jakarta Timur, Indonesia)

Received 09 July 2021, Accepted 26 July 2021, Published 04 August 2021

\section{PENDAHULUAN}

Matematika adalah pelajaran yang penting dan perlu diajarkan mulai dari pra sekolah hingga perguruan tinggi (Ikhsan \& Anshari, 2016). Matematika berisi pembelajaran yang penuh dengan symbol, rumus yang membuat siswa butuh waktu untuk memahaminya, abstrak, logis dan teratur (Santri, 2017) sehingga siswa harus banyak berlatih melalui soal pada materi yang diajarkan (Ikhsan \& Anshari, 2016). Oleh sebab itu matematika termasuk mata pelajaran yang tidak mudah dipelajari dan menakutkan bagi banyak siswa (Wijaya et al., 2019) sehingga menyebabkan siswa merasa tidak tertarik pada matematika (Pujiastuti, 2020). Ketika seseorang merasa tidak tertarik, tidak nyaman dan menyebabkan kurang maksimalnya orang tersebut dalam melakukan sesuatu disebut kecemasan (Suardana \& Simarmata, 2013). 
Setiap siswa memiliki kecemasan yang berbeda-beda, tergantung pada kegemaran dan kecenderungan siswa pada mata pelajaran tertentu (Anita, 2014). Apabila saat pembelajaran matematika siswa mengalami ciri-ciri seperti merasa panik, ebingungan, depresi, cemas disertai berbagai reaksi psikologis, seperti berkeringat dan wajah menjadi pucat, maka siswa tersebut sedang mengalami kecemasan matematika (Ekowati et al., 2021). Kecemasan matematika dapat mengakibatkan siswa mengalami kesulitan dalam belajar matematika (Ekowati et al., 2021) seperti tidak dapat menyelesaikan permasalahan matematika dengan kreatif Apriliani \& Suyitno (2016) dan rendahnya kemampuan koneksi matematis siswa (Anita, 2014).

Kecemasan matematika siswa juga dapat menghambat siswa dalam pemecahan masalah (Irfan, 2017). Hal tersebut terjadi karena saat siswa yang memiliki kecemasan yang tinggi dapat mengalami kesalahan dalam penulisan symbol matematika, pemaknaan model matematika, dan kurang konsistennya siswa dalam penggunaan symbol matematika (Irfan, 2017). Kecemasan akan berdampak baik apabila kecemasan tersebut masih dapat dikendalikan dan dalam kategori wajar (Pujiastuti, 2020). Namun apabila siswa memiliki kecemasan yang tinggi, maka hal tersebut dapat mengganggu psikis dan kesehatan mental siswa (Suardana \& Simarmata, 2013). Selain itu siswa yang memiliki kecemasan yang rendah memiliki prestasi yang lebih tinggi dibandingkan dengan siswa yang memiliki kecemasan yang tinggi (Suardana \& Simarmata, 2013). Kecemasan matematika memiliki hubungan negative dengan prestasi belajar (Santri, 2017). Semakin besar nilai kecemasan matematika maka semakin kecil nilai hasil belajar matematika siswa (Disai et al., 2018; Pujiastuti, 2020). Selain kecemasan matematika, factor yang dapat memengaruhi prestasi belajar anak adalah motivasi (Santana et al., 2018).

Motivasi adalah salah satu factor yang dapat memengaruhi prestasi belajar anak (Santana et al., 2018). Menurut Suardana \& Simarmata (2013) motivasi merupakan pendorong siswa dalam mendapatkan keinginan, mengarahkan minat bakat dan mencapai prestasi. Motivasi belajar dapat dikelompokkan menjadi dua yakni motivasi instrinsik (suatu dorongan yang di dapat dari dalam individu) dan motivasi ekstrinsik (suatu dorongan yang didapatkan dari keadaan luar individu) (Emda, 2017). Demi mencapai tujuan pembelajaran yang optimal, kedua kelompok motivasi tersebut harus ada pada diri siswa (Emda, 2017).

Faktor yang dapat memengaruhi motivasi dalam belajar yaitu kemampuan siswa, impian dan aspirasi siswa, kondisi siswa dan kondisi lingkungan siswa (Emda, 2017). Emda (2017) mengungkapkan bahwa siswa yang memiliki motivasi belajar ditandai dengan ciri-ciri seperti bersungguh-sunguh dalam mengerjakan pekerjaan, bahagia melakukan sesuatu sendiri, adanya ketertarikan pada banyak masalah, tegar saat bertemu hal yang rumit, merasa bosan pada tugas yang selalu sama, teguh pendirian dan suka mencari dan menyelesaikan berbagai soal.

Motivasi dan belajar merupakan dua hal yang saling mempengaruhi (Suardana \& Simarmata, 2013). Adanya motivasi belajar dapat mendorong semangat belajar pada siswa (Nurmala, Desy ayu., 2014). Penelitian Nurmala, Desy ayu (2014) menghasilkan motivasi belajar memiliki pengaruh pada aktivitas belajar dan motivasi belajar juga memiliki pengaruh pada hasil belajar. Siswa yang memiliki motivasi yang rendah terlihat tidak perhatian, mudah putus asa, serta dapat mengalami kesulitan dalam kegiatan belajar 
(Nurmala, Desy ayu., 2014). Hal tersebut bisa mengakibatkan siswa tidak berupaya untuk mengekspresian seluruh kemampuannya sehingga siswa kurang berhasil dalam pembelajarannya (Emda, 2017; Ikhsan \& Anshari, 2016). Selain motivasi belajar siswa, factor lain yang dapat memengaruhi hasil belajar siswa adalah gender (Imro'ah et al., 2019).

Perbedaan gender dapat menimbulkan perbedaan fisiologi dan memengaruhi perbedaan psikologis dalam belajar (MZ, 2013). Wijaya (2019) mendapatkan hasil penelitian bahwa siswa perempuan terlihat lebih santai dibandingkan laki-laki. Laki-laki dan perempuan memiliki berbagai perbedaan yang mengakibatkan perbedaan cara berpikir dan cara menyelesaikan masalah dalam belajar (Wijaya et al., 2019). Jika dibandingkan dengan siswa perempuan, siswa laki-laki memiliki kemampuan representasi dan kemampuan bahasa verbal yang lebih tinggi (Dewi et al., 2017). Gender adalah salah satu factor yang dapat mempengaruhi kemampuan komukasi matematis (Hodiyanto, 2017). Siswa perempuan memiliki keunggulan dalam keakuratan, kehati-hatian dan ketelatenan berpikir (Wijaya et al., 2019). Selain itu, siswa perempuan memiliki hasil belajar yang lebih unggul dari pada siswa laki-laki (Habibullah, 2014)

Hasil belajar juga dapat dipengaruhi oleh proses belajar (Nurmala, Desy ayu., 2014). Proses belajar adalah sesuatu yang dilakukan seseorang dengan tujuan untuk memahami dan menguasai ilmu (Suardana \& Simarmata, 2013). Sehubungan dengan proses belajar, Sejak Maret 2020 Kementerian Pendidikan dan Kebudayaan memberlakukan kegiatan belajar dari rumah sebagai upaya mencegah peyebaran virus COVID-19. Di masa pandemic COVID-19, system pembelajaran berubah dari yang biasanya tatap muka menjadi pembelajaran daring.

Pembelajaran daring merupakan salah satu konsep dan teknologi di era 4.0 (Vera Mandailina et al., 2021). Pembelajaran daring merupakan salah satu metode yang menggunakan elektronik, dapat dilaksanakan dengan jarak jauh dan bisa memberikan kemudahan bagi siswa untuk menemuan bermacammacam ilmu yang diperlukan untuk membantu pembelajarannya (Cahyani et al., 2020). Konsep pembelajaran daring membuat pembelajaran dapat berlangsung kapan saja dan dimana saja walaupun tidak satu ruangan dengan pengajar (Sur et al., 2020). Pembelajaran daring memiliki dampak seperti terjadi kecemasan pada mahasiswa (Irwanto et al., 2021), menurunkan motivasi belajar siswa bahkan bisa berpengaruhi terhadap hasil belajar siswa (Cahyani et al., 2020) dan guru mengalami kesulitan untuk mengontrol dan menjaga iklim belajar karena terbatas dalam ruang virtual (Cahyani et al., 2020). Berdasarkan pemaparan diatas, peneliti tertarik untuk melaksanakan penelitian dengan tujuan untuk mengetahui tingkat kecemasan dan motivasi belajar siswa terhadap matematika berdasarkan gender di masa pandemic COVID-19. Untuk dapat lebih jelas, kerangka berpikir disajikan pada Gambar 1. 


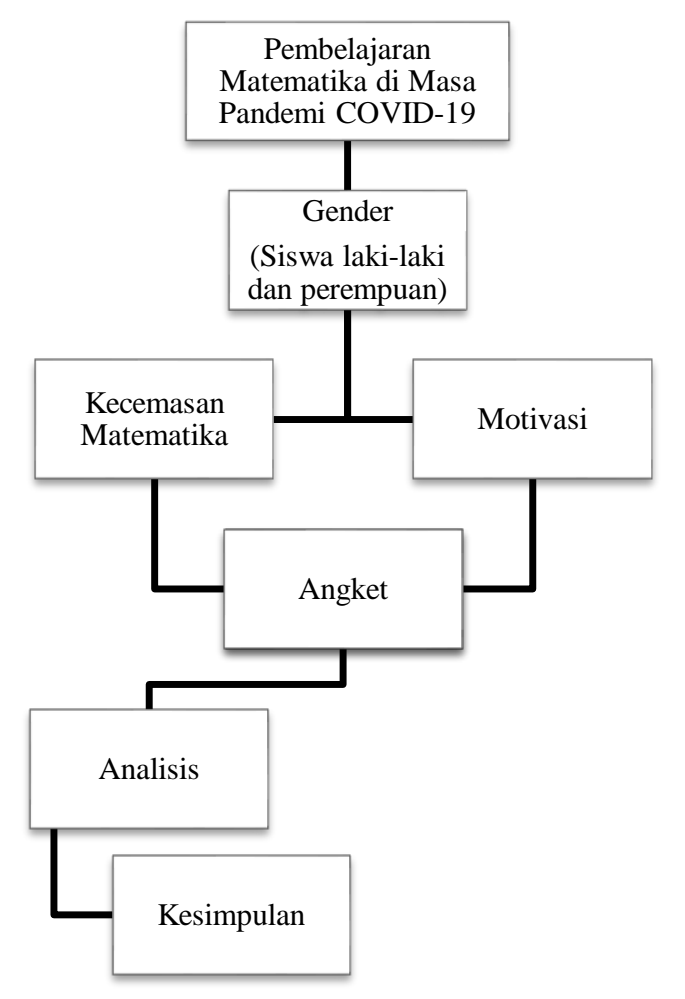

Gambar 1. Bagan Skema Kerangka Berpikir

\section{METODE}

Penelitian ini menggunakan jenis penelitian kuantitatif. Populasi pada penelitian ini adalah seluruh siswa SMP Negeri di Jakarta Selatan kelas 8 tahun ajaran 2020/2021. Sampel yang digunakan adalah 451 siswa, didapatkan dari perhitungan menggunakan Formula Estok Nevitte Cowan (Karami, 2018) guna mendapatkan ukuran sampel yang representative.

Instrumen penelitian diadaptasi dari Suren \& Ali Kandemir (2020) yang dimodifikasi sesuai persoalan pada penelitian ini.. Instrumen yang digunakan pada penelitian ini adalah instrument kecemasan matematika dan motivasi belajar siswa. Instrumen kecemasan matematika terbagi dalam 5 indikator yaitu sikap, kepercayaan diri, pengetahuan konten matematika, kegiatan belajar, dan ujian. Instrumen motivasi belajar siswa terbagi dalam 5 indikator yaitu orientasi tujuan intrinsic, orientasi tujuan ekstrinsik, nilai tugas, keyakinan dan efikasi diri. Instrumen berbentuk kuisioner. Sebelum disebarluaskan, instrument telah melalui proses validasi dengan seorang pakar di bidang matematika dan seorang pakar di bidang Bahasa. Instrumen disebarluaskan secara online melalui google form.

Analisis yang digunakan dalam penelitian ini adalah analisis deskriptif. Analisis deskriptif dilakukan dengan tujuan untuk mengetahui tingkat kecemasan matematika dan motivasi belajar siswa. Pada analisis ini tercantum mean dan nilai simpangan baku pada setiap indikator. Tabel 1 menunjukkan interpretasi kuisioner kecemasan matematika dan motivasi belajar matematika (Suren \& Ali Kandemir, 2020, p.198). 
Tabel 1. Interpretasi Kuisioner

\begin{tabular}{|c|c|}
\hline Nilai Rata-Rata & Interpretasi \\
\hline $1,00-1,79$ & Sangat Rendah \\
\hline $1,80-2,59$ & Rendah \\
\hline $2,60-3,39$ & Sedang \\
\hline $3,40-4,19$ & Tinggi \\
\hline $4,20-5,00$ & Sangat Tinggi \\
\hline
\end{tabular}

Hasil analisis deskripsi kemudian dikaitkan dengan interpretasi kuisioner untuk penarikan kesimpulan. Analisis data pada penelitian ini dihitung menggunakan software Microsoft Excel 2010.

\section{HASIL DAN DISKUSI}

\section{Hasil}

Tabel 2 menunjukkan hasil analisis deskriptif kecemasan matematika siswa SMP kelas 8 di Jakarta Selatan.

Tabel 2. Analisis Deskriptif Kecemasan Matematika

\begin{tabular}{|l|c|c|c|}
\hline \multicolumn{1}{|c|}{ Indikator Kecemasan Matematika } & Gender & Mean & SS \\
\hline \multirow{2}{*}{ Sikap } & Laki-laki & 1,95 & 1,11 \\
\cline { 2 - 4 } & Perempuan & 2,05 & 0,05 \\
\hline \multirow{2}{*}{ Kepercayaan Diri } & Laki-laki & 2,65 & 1,34 \\
\cline { 2 - 4 } & Perempuan & 2,89 & 0,05 \\
\hline \multirow{2}{*}{ Pengetahuan Konten Matematika } & Laki-laki & 2,38 & 1,18 \\
\cline { 2 - 4 } & Perempuan & 2,57 & 0,08 \\
\hline \multirow{2}{*}{ Kegiatan Belajar } & Laki-laki & 3,59 & 1,24 \\
\cline { 2 - 4 } & Perempuan & 3,89 & 0,08 \\
\hline \multirow{2}{*}{ Ujian } & Laki-laki & 2,97 & 1,44 \\
\cline { 2 - 4 } & Perempuan & 3,24 & 0,06 \\
\hline \multirow{2}{*}{ Kecemasan Matematika Secara Keseluruhan } & Laki-laki & 2,72 & 0,13 \\
\cline { 2 - 4 } & Perempuan & 2,93 & 0,01 \\
\hline
\end{tabular}

Berdasarkan Tabel 2, indikator dengan mean tertinggi terdapat pada indikator kegiatan belajar pada siswa perempuan $(\bar{x}=3,89$ dan SS $=0,08)$. Pada siswa laki-laki mean tertinggi juga terdapat pada indikator kegiatan belajar $(\bar{x}=3,59$ dan SS $=1,24)$. Hal tersebut memberi arti bahwa kegiatan belajar memberikan efek yang paling tinggi dalam kecemasan matematika. Anita (2014) menjelaskan bahwa proses belajar mengajar matematika di kelas merupakan salah satu penyebab kecemasan matematika.

Indikator dengan mean terendah pada siswa perempuan adalah indikator sikap $(\bar{x}=2,05$ dan $\mathrm{SS}=$ 0,05). Begitu juga pada siswa laki-laki, indikator dengan mean terrendah terdapat pada indikator sikap $(\bar{x}=$ $1,95$ dan SS $=1,11)$. Hal tersebut berarti sikap siswa memberikan kecemasan matematika yang paling rendah dibandingkan faktor lain.

Pada setiap indikator siswa perempuan selalu memiliki mean yang lebih tinggi dari siswa laki-laki. Secara keseluruhan siswa perempuan juga memiliki mean yang lebih tinggi $(\bar{x}=2,93$ dan SS $=0,01)$ dari pada laki-laki $(\bar{x}=2,72$ dan SS $=0,13)$. Hal tersebut membuktikan bahwa tingkat kecemasan yang lebih tinggi dimilii oleh siswa perempuan. Kesimpulan itu tidak sejalan dengan Nofrialdi(2018) yang menemukan bahwa tingkat kecemasan yang lebih tinggi berdasarkan gender dimiliki oleh siswa laki-laki. Sementara itu 
secara keseluruhan kecemasan matematika siswa laki-laki dan siswa perempuan di masa pandemic COVID19 termasuk ke dalam kategori sedang. Tabel 3 menunjukkan hasil analisis deskriptif motivasi belajar siswa SMP kelas 8 di Jakarta Selatan.

Tabel 3. Analisis Deskriptif Motivasi Belajar

\begin{tabular}{|l|c|c|c|}
\hline \multicolumn{1}{|c|}{ Indikator Motivasi Belajar } & Gender & Mean & SS \\
\hline \multirow{2}{*}{ Orientasi Tujuan Intrinsik } & Laki-laki & 3,41 & 1,09 \\
\cline { 2 - 4 } & Perempuan & 3,52 & 0,02 \\
\hline \multirow{2}{*}{ Orientasi Tujuan Ekstrinsik } & Laki-laki & 4,45 & 0,88 \\
\cline { 2 - 4 } & Perempuan & 4,68 & 0,20 \\
\hline \multirow{2}{*}{ Nilai Tugas } & Laki-laki & 3,45 & 1,06 \\
\cline { 2 - 4 } & Perempuan & 3,54 & 0,06 \\
\hline \multirow{2}{*}{ Keyakinan } & Laki-laki & 4,13 & 0,93 \\
\cline { 2 - 4 } & Perempuan & 4,23 & 0,12 \\
\hline \multirow{2}{*}{ Efikasi Diri } & Laki-laki & 3,53 & 1,11 \\
\cline { 2 - 4 } & Perempuan & 3,46 & 0,08 \\
\hline \multirow{2}{*}{ Motivasi Belajar Secara Keseluruhan } & Laki-laki & 3,79 & 0,10 \\
\cline { 2 - 4 } & Perempuan & 3,89 & 0,07 \\
\hline
\end{tabular}

Berdasarkan Tabel 3, indikator dengan mean tertinggi terdapat pada indikator orientasi tujuan ekstrinsik pada siswa perempuan $(\bar{x}=4,68$ dan SS $=0,20)$ dan termasuk ke dalam kategori tinggi. Pada siswa laki-laki mean tertinggi juga terdapat pada indikator orientasi tujuan ekstrinsik $(\bar{x}=4,45$ dan SS $=$ 0,88 ) dan termasuk ke dalam kategori tinggi. Indikator orientasi tujuan ekstrinsik berisi tentang rasa ingin dan bangga apabila mendapat nilai yang bagus. Indikator ini mendapat nilai mean tertinggi, yang berarti siswa memiliki motivasi yang tinggi saat siswa ingin memperoleh nilai yang bagus pada pelajaran matematika. Memperoleh nilai yang bagus bisa saja mengundang pujian atau reward yang membuat siswa lebih termotivas untuk belajar (Warti, 2018).

Indikator dengan mean terendah pada siswa perempuan adalah indikator efikasi diri $(\bar{x}=3,46$ dan SS $=0,08)$ namun masih termasuk ke dalam kategori tinggi. Sedangkan pada siswa laki-laki, indikator dengan mean terrendah terdapat pada indikator orientasi tujuan intrinsik $(\bar{x}=3,41$ dan $\mathrm{SS}=1,09)$ namun masih termasuk ke dalam kategori tinggi. Hal tersebut berarti siswa perempuan memiliki motivasi yang rendah pada kepercayaan dirinya saat belajar matematika dan siswa laki-laki memiliki dorongan yang rendah dari dirinya sendiri untuk belajar.

Jika dibandingkan dengan siswa laki-laki, pada indikator orientasi tujuan intrinsik, orientasi tujuan ekstrinsik, nilai tugas dan keyakinan siswa perempuan memiliki nilai mean yang lebih besar. Sedangkan siswa laki-laki memiliki nilai mean lebih besar dari siswa perempuan hanya pada indikator efikasi diri. Secara keseluruhan siswa perempuan juga memiliki mean yang lebih tinggi $(\bar{x}=3,89$ dan SS $=0,07)$ dari pada laki-laki $(\bar{x}=3,79$ dan SS $=0,10)$. Hal tersebut berarti motivasi yang lebih tinggi dimiliki oleh siswa perempuan. Santana (2018) juga memiliki hasil yang sama yaitu motivasi belajar siswa perempuan lebih tinggi daripada motivasi belajar siswa laki-laki. Namun tak bisa dipungkiri bahwa siswa laki-laki dan perempuan memiliki motivasi yang tinggi pada masa pandemic COVID-19 ini. Hal tersebut sejalan dengan Vera Mandailina (2021) yang menjelaskan bahwa pembelajaran daring dapat meningkatkan motivasi dan 
hasil belajar siswa. Selain itu Sur (2020) juga menemukan bahwa pelaksanaan perkuliahan online berakibat adanya peningkatan motivasi belajar mahasiswa.

\section{Diskusi}

Penelitian ini memberikan hasil siswa perempuan memiliki tingkat kecemasan matematika yang lebih tinggi dibandingkan siswa laki-laki di masa pandemic COVID-19. Hal tersebut terbukti dengan perolehan mean dari kecemasan matematika siswa perempuan $(\bar{x}=2,93$ dan SS $=0,01)$ dan siswa laki-laki $(\bar{x}=2,72$ dan SS $=0,13$ ). Hal tersebut sejalan dengan penelitian Jayantika (2020) bahwa mahasiswa perempuan memiliki kecemasan matematika lebih tinggi dibandingkan mahasiswa laki-laki. Terkait dengan kecemasan matematika, jika dibandingkan dengan laki-laki, siswa perempuan mengalami kesulitan dalam menyelesaikan masalah, berpikiran kurang logis, kurang percaya diri dan memiliki emosional yang tinggi (FEDI \& Suparta, 2014). Sedangkan adanya kemampuan untuk menyelesaikan masalah, berpikiran logis, kepercayaan diri merupakan hal yang mendukung pembelajaran matematika (FEDI \& Suparta, 2014).

Selain itu, motivasi belajar yang lebih tinggi juga didapatkan dari perolehan mean siswa perempuan $(\bar{x}=3,89$ dan SS $=0,07)$ yang lebih tinggi dari siswa laki-laki $(\bar{x}=3,79$ dan SS $=0,10)$. Hasil tersebut sejalan dengan Santana et al. (2018) bahwa siswa perempuan memiliki motivasi belajar yang lebih tinggi dibandingan dengan siswa laki-laki. Motivasi yang tinggi bisa didapatkan dari berbagai factor, seperti dari dalam diri sendiri ataupun dari lingkungan luar diri siswa.

Hasil penelitian ini didapatkan sesuai dengan kondisi siswa yang melakukan pembelajaran daring di masa pandemic COVID-19. Penelitian ini tentunya memiliki kekurangan yakni sampel partisipan yang terbatas hanya dari daerah tempat tinggal penulis. Oleh karena itu, hasil penelitian ini belum tentu dapat digeneralisasikan pada semua siswa SMP.

\section{KESIMPULAN}

Hasil dari penelitian ini adalah di masa pandemic COVID-19 ini, siswa perempuan memiliki tingkat kecemasan matematika yang lebih tinggi dibandigkan siswa laki-laki. Kecemasan matematika siswa secara keseluruhan termasuk ke dalam kategori sedang. Selain itu siswa perempuan juga memiliki tingkat motivasi yang lebih tinggi daripada siswa laki-laki. Kabar baik bahwa di masa pandemic ini siswa memiliki motivasi yang tinggi.

\section{REFERENSI}

Anita, I. W. (2014). Pengaruh Kecemasan Matematika (Mathematics Anxiety) Terhadap Kemampuan Koneksi Matematis Siswa Smp. Infinity Journal, 3(1), 125. https://doi.org/10.22460/infinity.v3i1.43 Apriliani, L. R., \& Suyitno, H. (2016). Kemampuan Berpikir Kreatif Matematis Berdasarkan Kecemasan Matematika Pada Pembelajaran Creative Problem Solving Berteknik Scamper. Ujmer, 5(2), 131-140. Cahyani, A., Listiana, I. D., \& Larasati, S. P. D. (2020). Motivasi Belajar Siswa SMA pada Pembelajaran Daring di Masa Pandemi Covid-19. IQ (Ilmu Al-Qur'an): Jurnal Pendidikan Islam, 3(01), 123-140. https://doi.org/10.37542/iq.v3i01.57 
Dewi, I., Saragih, S., \& Khairani, D. (2017). Analisis Peningkatan Kemampuan Representasi Matematis Siswa SMA Ditinjau dari Perbedaan Gender. Jurnal Didaktik Matematika, 4(2), 115-124. https://doi.org/10.24815/jdm.v4i2.8863

Disai, W. I., Dariyo, A., \& Basaria, D. (2018). Hubungan Antara Kecemasan Matematika Dan Self-Efficacy Dengan Hasil Belajar Matematika Siswa Sma X Kota Palangka Raya. Jurnal Muara Ilmu Sosial, Humaniora, Dan Seni, 1(2), 556. https://doi.org/10.24912/jmishumsen.v1i2.799

Ekowati, C. K., Samo, D. D., \& Njuka, K. T. N. (2021). Pengaruh Kecemasan, Kesulitan Belajar, dan Motivasi Belajar Terhadap Hasil Matematika Siswa Kelas VIII SMP Negeri 8 Kupang. 1(1), 31-38.

Emda, A. (2017). Kedudukan Motivasi Belajar Siswa Dalam Pembelajaran. Lantanida Journal, 5(2), 93 196. https://doi.org/10.22373/lj.v5i2.2838

FEDI, S., \& Suparta, M. (2014). Tingkat Kecemasan Dan Apresiasi Matematika Ditinjau Dari Gender Pada Siswa Kelas Viii Smp Negeri Sekecamatan Poco Ranaka Barat, Kabupaten Manggarai Timur Tahun Ajaran 2013/2014. Jurnal Jurusan Pendidikan Matematika Ganesha, 3(1), 103476.

Habibullah. (2014). REFLEKSI GENDER DALAM PEMBELAJARAN KURIKULUM 2013; STUDI TERHADAP HASIL BELAJAR IPS SISWA KELAS MODEL DI SOLOK, SUMATERA BARAT. 232249.

Hodiyanto, H. (2017). Pengaruh model pembelajaran problem solving terhadap kemampuan komunikasi matematis ditinjau dari gender. Jurnal Riset Pendidikan Matematika, 4(2), 219. https://doi.org/10.21831/jrpm.v4i2.15770

Ikhsan, M., \& Anshari, B. I. (2016). Peningkatan Kemampuan Pemahaman dan Motivasi Siswa SMP melalui Model Missouri Mathematics Project (MMP) dengan Menggunakan Game Matematika Online. Jurnal Didaktik Matematika, 3(1), 55-63. https://doi.org/10.24815/jdm.v3i1.4637

Imro'ah, S., Winarso, W., \& Baskoro, E. P. (2019). Analisis Gender Terhadap Kecemasan Matematika Dan Self Efficacy Siswa. KALAMATIKA Jurnal Pendidikan Matematika, 4(1), 23-36. https://doi.org/10.22236/kalamatika.vol4no1.2019pp23-36

Irfan, M. (2017). Analisis Kesalahan Siswa dalam Pemecahan Masalah Berdasarkan Kecemasan Belajar Matematika. Kreano, Jurnal Matematika Kreatif-Inovatif, 8(2), 143-149. https://doi.org/10.15294/kreano.v8i2.8779

Irwanto, E., Farhanto, G., Jasmani, P., \& Banyuwangi, U. P. (2021). Anxiety Pembelajaran Daring di Era Covid-19: pada Matakuliah Praktikum. 7(2), 264-269.

Jayantika, I. G. A. N. T. (2020). Kecemasan Matematis (Math Anxiety) dilihat dari Perbedaan Gender. KMahasaraswati Seminar Nasional Pendidikan Matematika (MAHASENDIKA) . IKIP PGRI Bali., 159-163.

Karami, R. A. (2018). Aplikasi SMS Gateway Quick Count Pemilu Berbasiskan PHP. JURNAL Al-AZHAR INDONESIA SERI SAINS DAN TEKNOLOGI, 4(2), 70. https://doi.org/10.36722/sst.v4i2.261

MZ, Z. A. (2013). Perspektif Gender Dalam Pembelajaran Matematika. Marwah: Jurnal Perempuan, Agama Dan Jender, 12(1), 15. https://doi.org/10.24014/marwah.v12i1.511 
Nofrialdi, I., Maison, M., \& Muslim, M. (2018). Tingkat Kecemasan Matematika Siswa SMA Negeri 2 Kerinci Kelas X MIA Sebelum Menghadapi Tes Matematika Berdasarkan Gender dan Hubungannya dengan Hasil Belajar. Edumatika: Jurnal Riset Pendidikan Matematika, 1(2), 11. https://doi.org/10.32939/ejrpm.v1i2.248

Nurmala, Desy ayu., L. E. P. dan N. S. (2014). Pengaruh Motivasi Belajar dan Aktivitas Belajar terhadap Hasil Belajar Akuntansi. Jurnal Pendidikan, Vol. 4,(1), No. 01.

Pujiastuti, H. (2020). PENGARUH KECEMASAN MATEMATIS DAN KONSEP DIRI TERHADAP HASIL BELAJAR MATEMATIKA SISWA. Jurnal Refleksi Edukatika, 4(2), 75-83. http://jurnal.umk.ac.id/index.php/RE\%0Ahttps://jurnal.umk.ac.id/index.php/RE/article/view/1222

Santana, K., Dewi, F. I. R., \& Budiarto, Y. (2018). Perbandingan Motivasi Belajar Siswa Kelas V Sd X, Y, Z Berdasarkan Jenis Kelamin Dan Partisipasi Bimbingan Belajar. Jurnal Muara Ilmu Sosial, Humaniora, Dan Seni, 1(2), 41. https://doi.org/10.24912/jmishumsen.v1i2.989

Santri, F. S. (2017). Ada Apa Dengan Kecemasan Matematika? Journal of Medives , 1(1), 59-65. http://ejournal.ikip-veteran.ac.id/index.php/matematika

Suardana, A. A. P. C. P., \& Simarmata, N. (2013). Hubungan Motivasi Belajar dan Kecemasan Menjelang Ujian. Jurnal Psikologi Udayana, 1(1), 203-212.

Sur, W. A. A., HasanahMinhatul, \& Mustofa, M. R. (2020). Analisis Motivasi Belajar Mahasiswa dengan Sistem Pembelajaran Daring Selama Masa Pandemi Covid-19. EQUATION Teori Dan Penelitian Pendidikan Matematika , ISSN 2599-3291 (Cetak), ISSN 2614-3933 (Online), 3(2), 40-54.

Suren, N., \& Ali Kandemir, M. (2020). The effects of mathematics anxiety and motivation on students' mathematics achievement. International Journal of Education in Mathematics, Science and Technology, 8(3), 190-218. https://doi.org/10.46328/IJEMST.V8I3.926

Vera Mandailina, Syaharuddin, Dewi Pramita, Ibrahim, \& Haifaturrahmah. (2021). Pembelajaran Daring Dalam Meningkatkan Motivasi dan Hasil Belajar Peserta Didik Selama Pandemi Covid-19: Sebuah Meta-Analisis. Indonesian Journal of Educational Science (IJES), 3(2), 120-129.

Warti, E. (2018). Pengaruh Motivasi Belajar Siswa terhadap Hasil Belajar Matematika Siswa di SD Angkasa 10 Halim Perdana Kusuma Jakarta Timur. Mosharafa: Jurnal Pendidikan Matematika, 5(2), 177-185. https://doi.org/10.31980/mosharafa.v5i2.273

Wijaya, R., Fahinu, F., \& Ruslan, R. (2019). Pengaruh Kecemasan Matematika dan Gender Terhadap Kemampuan Penalaran Adaptif Matematika Siswa SMP Negeri 2 Kendari. Jurnal Pendidikan Matematika, 9(2), 173. https://doi.org/10.36709/jpm.v9i2.5867 